\title{
Article \\ A Study of the Antimicrobial Activity of Combined Black Pepper and Cinnamon Essential Oils against Escherichia fergusonii in Traditional African Yoghurt
}

\author{
Betty A. Ogwaro ${ }^{1,2}$, Elizabeth A. O'Gara ${ }^{2,3}$, David J. Hill ${ }^{1,2}$ and Hazel Gibson ${ }^{1,2, *(1)}$ \\ 1 Faculty of Science and Engineering, Wolverhampton School of Sciences, University of Wolverhampton, \\ Wulfruna Street, Wolverhampton WV1 1LY, UK; B.A.Ogwaro@wlv.ac.uk (B.A.O.); D.Hill@wlv.ac.uk (D.J.H.) \\ 2 Faculty of Science and Engineering, Research Institute for Healthcare Science, University of Wolverhampton, \\ Wulfruna Street, Wolverhampton WV1 1LY, UK; E.OGara@wlv.ac.uk \\ 3 Faculty of Science and Engineering, School of Medicine and Clinical Practice, University of Wolverhampton, \\ Wufruna Street, Wolverhampton WV1 1LY, UK \\ * Correspondence: H.Gibson@wlv.ac.uk
}

Citation: Ogwaro, B.A.; O'Gara, E.A.; Hill, D.J.; Gibson, H. A Study of the Antimicrobial Activity of Combined Black Pepper and Cinnamon Essential Oils against Escherichia fergusonii in Traditional African Yoghurt. Foods 2021, 10, 2847. https://doi.org/ 10.3390/foods10112847

Academic Editor: Teresa Requena

Received: 15 October 2021

Accepted: 15 November 2021

Published: 18 November 2021

Publisher's Note: MDPI stays neutral with regard to jurisdictional claims in published maps and institutional affiliations.

Copyright: (c) 2021 by the authors. Licensee MDPI, Basel, Switzerland. This article is an open access article distributed under the terms and conditions of the Creative Commons Attribution (CC BY) license (https:// creativecommons.org/licenses/by/ $4.0 /)$.

\begin{abstract}
The antimicrobial activity of the essential oils of black pepper (BPE) and cinnamon bark (CE) extracts against E. fergusonii was assessed in pasteurized full cream milk during and postfermentation. The milk was fermented with $1 \%(v / v)$ of Lactobacillus delbrueckii subspecies bulgaricus (NCIMB 11778) and Streptococcus thermophilus (NCIMB 10387) (approx. $10^{6} \mathrm{cfu} / \mathrm{mL}$ each) and incubated and stored at $25{ }^{\circ} \mathrm{C}$ for 5 days $(144 \mathrm{~h})$ or at $43{ }^{\circ} \mathrm{C}$ for $24 \mathrm{~h}$ and then stored at $25{ }^{\circ} \mathrm{C}$ for $120 \mathrm{~h}$. The milk was spiked with E. fergusonii at the start of fermentation by the lactic acid bacteria (pre-fermentation contamination) for after fermentation (post fermentation contamination). BPE and CE were applied at concentrations based on their minimum inhibitory concentration of $0.5 \%$ and $0.25 \%$ respectively as follows: $0.5 \% \mathrm{BPE}$ alone; $0.125 \% \mathrm{BPE}$ with $0.1875 \% \mathrm{CE} ; 0.25 \% \mathrm{BPE}$ with $0.125 \%$ $\mathrm{CE} ; 0.375 \% \mathrm{BPE}$ with $0.0625 \% \mathrm{CE} ; 0.25 \% \mathrm{CE}$ alone. Results showed that during fermentation at $25{ }^{\circ} \mathrm{C}$, E. fergusonii grew to a similar level (approx. $10^{9} \mathrm{CFU} / \mathrm{mL}$ ) in control samples and $10^{8} \mathrm{CFU} / \mathrm{mL}$ when $\mathrm{BPE}$ or $\mathrm{CE}$ were added alone. Whereas, in the samples with the combined essential oils, the bacterium grew to $10^{6}-10^{7} \mathrm{CFU} / \mathrm{mL}$ only. During the milk fermentation at $43^{\circ} \mathrm{C}$, E. fergusonii grew to approx. $10^{9} \mathrm{CFU} / \mathrm{mL}$ in samples without treatment. However, it was not detected in samples containing mixed BPE with CE after 8,10 and $12 \mathrm{~h}$ of fermentation. Subsequent storage at $25{ }^{\circ} \mathrm{C}$ resulted in undetectable levels of the bacterium in all the samples treated with BPE or CE after $24 \mathrm{~h}$ of storage. These results indicated that BPE in combination with CE reduced growth during fermentation and was bactericidal during storage.
\end{abstract}

Keywords: natural antimicrobial; black pepper extract; cinnamon extract; Escherichia fergusonii; traditional yoghurt

\section{Introduction}

E. fergusonii is a Gram-negative, rod-shaped bacterium which is an infrequent but emerging multidrug-resistant human pathogen. It was reported by Farmer et al. [1] in 1985 as a new species of the genus Escherichia, family Enterobacteriaceae. It was formerly known as Enteric Group 10 due to its biochemically distinct nature compared to other species and bio-groups of Enterobacteriaceae. It is most closely related to Escherichia coli and Shigella sp. and more distantly related to other bacterial species of the family Enterobacteriaceae [2]. E. fergusonii is one of the five members of Escherichia which can be found in the intestines of human beings and can be pathogenic to animals and humans [3,4]. E. fergusonii has been isolated from human clinical samples collected from urine, blood, abdominal wounds, faeces and from gall bladder fluids of patients [5]. The bacterium was reported in calves and sheep with clinical cases suggestive of salmonellosis [6]. In horses, goats and ostriches, 
E. fergusonii was associated with symptoms of fibrinonecrotic typhlitis $[7,8]$. The prevalence of $E$. fergusonii in Africa is not yet well studied. Saad et al. [9] reported the presence of $E$. fergusonii in raw milk and some dairy products in Egypt. In 2017, Glover [10] isolated E. fergusonii from non-human primates in South Africa. Adesina [11] identified E. fergusonnii from non-clinical samples from patients in a general hospital in Lagos, Nigeria. Similarly, to other Escherichia spp., E. fergusonii grows optimally on routine culture media at $37-40{ }^{\circ} \mathrm{C}$ under aerobic conditions but its temperature range of growth extends up to $45^{\circ} \mathrm{C}[12,13]$ and according to Ingle et al. [14] E. fergusonii cannot replicate at temperatures below $11^{\circ} \mathrm{C}$.

Since 1985, there has been an increasing number of isolations of E. fergusonii in samples from veterinary and human origin, but limited information is known about its growth and survival in foods. The traditional African herders store their excess milk in the form of fermented products such as yoghurt, acidified milk, ghee or cheese to increase its shelf life $[15,16]$. The traditional farmers add herbs and spices to the milk for flavour and aroma [17]. A large proportion of these traditional products are prepared with raw milk [18] often with poor hygiene and sanitation facilities [19]. Today, herbs and spices form an integral part of foods for flavour and aroma, as well as preservatives and therapeutic agents. They are also used for medicinal preparations, cosmetics, perfumery, and various other products [20,21]. In addition, the WHO [22] noted that between $65 \%$ and $80 \%$ of the populations of developing countries use medicinal plants as remedies. Furthermore, there is considerable interest in the possible use of natural functional plants as alternative food additives either to prevent the growth of food pathogens or delay the onset of food spoilage [23-25]. Essential oils (EOs) from aromatic plants have a high content of bioactive compounds and have widely been used for their bactericidal effects in medical and pharmaceutical fields [26].

Black pepper (Piper nigrum) and cinnamon (Cinnamomum zeylanicum) are among the spices used in traditional African fermented foods and dairy products [27]. Black pepper, a member of the family Piperaceae, is the most famous spice for flavouring foods throughout the world due to the pungency of its major bioactive component, piperine [26]. Black pepper also contains a wide range of phytochemicals [28]. Besides piperine, it has monoterpenes (camphene, pinene, limonene), other alkaloids [piperinigramides, A-G; piperic ester, pipernigrester $\mathrm{A}]$ and flavonoids, which have antimicrobial activities against a range of microorganisms [29]. Moreover, black pepper contains $8 \%$ moisture, $10 \%$ protein, $10.2 \%$ lipid, $66.5 \%$ carbohydrate, $4.6 \%$ ash and vitamins [30]. Since olden times, Piper nigrum has been used aroma and flavour, as well as for medicinal purposes in many parts of the world [31]. Although Nagavekar and Singhal [32] noted that the antimicrobial activities of Piper nigrum are due to the presence of oleoresins, in general, the antimicrobial activity of black pepper is primarily due to piperine [33].

Cinnamon (C. zeylanicum) on the other hand is from the Lauraceae family. It is a common spice in the preparation of tea and beverages in the world. It contains $9.5-10.5 \%$ moisture, $3.89-4.65 \%$ protein, $59.55-80.59 \%$ carbohydrate, $53.1 \%$ dietary fibre, $3.55 \%$ ash and vitamins [34]. Cinnamaldehyde is the major component of cinnamon bark and cinnamon sticks comprising between $60-90 \%$ of the component [35]. Cinnamaldehyde has also been reported to be active as an antibacterial, anti-allergic, anti-ulcerogenic, antipyretic and antioxidant [36-39]. However, cinnamaldehyde does not affect the growth of Lactobacillus species in yoghurt [40]. Traditional herders incorporate cinnamon in fermenting milk for its flavour and aroma. E. fergusonii is an infrequent but emerging multidrug-resistant human pathogen and there are reports in the literature that E. fergusonii exhibits acquired resistance to a spectrum of antibiotics [41-44]. With a lack of refrigeration facilities, the traditional farmers ferment excess milk to produce yoghurt and extend the shelf life. However, fermentation acids alone are not enough to control microbial growth.

This study aimed to assess the antimicrobial activity of BPE and/or CE against E. fergusonii in full cream milk during or post-fermentation by lactic acid bacteria. The milk was incubated at $25^{\circ} \mathrm{C}$ mimicking the traditional African yoghurt fermentation temperature or $43{ }^{\circ} \mathrm{C}$ mimicking the industrial temperature. 


\section{Materials and Methods}

\subsection{Media for Growth}

Tryptone Soy Broth (TSB, LAB004) Tryptone Soy Agar (TSA, LAB011); de Man-RogosaSharpe Agar (MRSA LAB098); de Man Rogosa-Sharpe Broth (MRSB LAB093) and M17 Agar (LAB092) were all purchased from Lab M Limited, Bury, UK, and M17 Broth (CM0817) was purchased from Thermo Fisher Scientific (Loughborough, UK); All media were prepared according to the manufacturers' instructions. M17 Agar and M17 broth were used for S. salivirus subspecies thermophilus [45]. $50 \mathrm{~mL}$ of $10 \%$ sterilized lactose was added to 1 litre of M17A or M17B before use (46). The sample was tested by streaking on the agar or inoculating in the broth using a typical $S$. thermophilus colony and incubated at $37^{\circ} \mathrm{C}$ for $24 \mathrm{~h}$ [46]. MRSA and MRSB were used for the enumeration of L. delbrueckii subspecies bulgaricus [47], and Violet Red Bile Agar (VRBA, CM0107B, Thermo Fischer Scientific, Loughborough, UK) for the enumeration of E. fergusonii. Sterile quarter-strength Ringers Solution (BR 0052, Thermo Fischer Scientific, Loughborough, UK) was used as an isotonic diluent for the bacterial cells. All media were prepared with deionized water. The commercial MRS agar had Tween $80(1.08 \mathrm{~g} / \mathrm{L})$ included in the composition of the agar. Thus, no additional components were added to MRSB or MRSA media.

\subsection{Microorganisms and Culture Conditions}

Escherichia fergusonii (UCC 585) was an isolate from a traditional African yoghurt, L. delbrueckii subspecies bulgaricus (NCIMB 11778) and S. thermophilus (NCIMB 103687) were obtained from the National Collection of Industrial Food and Marine Bacteria (Aberdeen, UK). Before each experiment, culture from a freeze-dried vial, maintained at $-20^{\circ} \mathrm{C}$ was activated in TSB for E. fergusonii; and in M17 Broth [pH $6.4 \pm 0.2]$ for S. thermophilus. Cultures were incubated for $24 \mathrm{~h}$ at $37^{\circ} \mathrm{C} \pm 0.1^{\circ} \mathrm{C}$ and streaked onto TSA and M17 Agar, respectively. L. delbrueckii subspecies bulgaricus was activated in MRSB, pH $5.5 \pm 0.2$ and incubated under anaerobic conditions at $43 \pm 0.1^{\circ} \mathrm{C}$ for $48-72 \mathrm{~h}$. The cultures were then streaked on MRSA ( $\mathrm{pH} 5.5 \pm 0.2$ ) and incubated in an anaerobic gas jar at $43 \pm 0.1{ }^{\circ} \mathrm{C}$ for 48-72 h. Resuscitated microorganisms were sub-cultured twice before use in the experiments. All activated cultures were maintained on slants at $4{ }^{\circ} \mathrm{C}$ and were sub-cultured monthly. The $\mathrm{pH}$ of the media was adjusted carefully with $1 \mathrm{~N} \mathrm{HCL}$.

To prepare the inoculum, one pure isolated colony from an agar plate was transferred to TSB for E. fergusonii, M17B [pH 6.4 \pm 0.2 ] for S. thermophilus and MRSB [pH $5.5 \pm 0.2$ ] for L. delbrueckii subspecies bulgaricus. L. delbrueckii subspecies bulgaricus was incubated in an anaerobic gas jar (either 1-litre or 2.5-litre gar jar with a corresponding gas pack). All the broth cultures were incubated at $37^{\circ} \mathrm{C}$ for $24 \mathrm{~h}$ with shaking $(150 \mathrm{rpm})$. A preliminary assessment was carried out to determine growth and survival of the starter cultures in pasteurized full cream milk with various inoculum sizes and it was found that approx. $10^{6} \mathrm{CFU} / \mathrm{mL}$ produced a yoghurt with appropriate coagulation and aroma. It was also determined that both black pepper and cinnamon extract did not affect the growth of the two starter cultures during fermentation. To obtain the viable counts for E. fergusonii during the antimicrobial challenge test, serial dilutions were made in $\frac{1}{4}$ strength Ringer's solution and $100 \mu \mathrm{L}$ was plated out on VBRA; incubated for $24 \mathrm{~h}$ at $37^{\circ} \mathrm{C}$. Viable counts were recorded after the incubation period.

\subsection{Pre-Oil Extraction Preparation}

Black pepper seeds and cinnamon bark were purchased from a local market in Juba (South Sudan). The spices were first washed with sterile distilled water then dried in a drying cabinet at $50^{\circ} \mathrm{C}$ for $72 \mathrm{~h}$. The dried spices were then crushed first individually using a sterilized mortar and then ground with an electric grinder to coarse smaller particles before extraction. 


\subsection{Extraction of Essential Oils}

The essential oils (EOs) of black pepper and cinnamon bark were extracted using the Soxhlet extractor according to the methods of Soxhlet [48]. In the first step, $100 \mathrm{~g}$ of ground powder of each spice was individually weighed on a calibrated analytical balance directly in a $50 \mathrm{~mL}$ porous extraction thimble made from thick filter paper, which was then placed inside the main chamber of the Soxhlet extractor. $500 \mathrm{~mL}$ of HPLC grade methanol (Sigma Aldrich, Gillingham, UK) was put in a $1000 \mathrm{~mL}$ round bottom flask which was then placed on an electric heater. The heater was turned on to methanol's boiling point $\left(50^{\circ} \mathrm{C}\right)$. Continuous extraction took place by refluxing the solvent until the extraction was completed. The extraction was left to continue until the solvent was observed to be completely colourless and was left to reflux for a further 2-3 refluxes to ensure complete extraction.

The methanol was evaporated off using a rotary evaporator at a fixed temperature of $50{ }^{\circ} \mathrm{C}$ until all the methanol was completely evaporated, leaving a thick essential oil. The samples were kept at $-20^{\circ} \mathrm{C}$ until use (used within one month). The composition of EOs from the spices was determined in University's laboratory by Gas Chromatography-Mass spectrometry (data not presented). The main compounds in the cinnamon bark EO were cinnamaldehyde $(83.5 \%)$ and eugenol $(1.02 \%)$ and in black pepper seeds were piperine $(63.9 \%)$ and caryophyllene $(6.5 \%)$.

\subsection{Milk Sample Preparation}

Whole, full cream pasteurized milk ( $\mathrm{pH} 6.7 \pm 0.1$ ) with $3.5 \%$ fat was used in this study. The milk was purchased from a supermarket one day before the experiment was performed and at least 6 to 7 days before its use-by date. Sterile test tubes containing $10 \mathrm{~mL}$ of milk were heated by steam for $30 \mathrm{~min}$ at $85^{\circ} \mathrm{C}$ and transferred immediately to cool in a water bath set at $40^{\circ} \mathrm{C}$. The sterility of the samples was confirmed by streaking onto Petri dishes of TSA and incubating at $37^{\circ} \mathrm{C}$ for $24 \mathrm{~h}$. The milk samples were used to prepare the different concentrations of antimicrobials in milk.

\subsection{Determination of Minimum Inhibitory Concentration (MIC)}

First, a stock solution of $1 \%(v / v)$ of each EO extract was prepared in methanol (solvent). To determine the minimum inhibitory concentration of the EOs, 12 test tubes each containing $5.0 \mathrm{~mL}$ of pasteurized milk were set up. From the $1.0 \%$ of spice extract, a 2-fold serial dilution was carried out in tubes $1-10$ to give 1 to $0.156 \%$. The 11 th and 12 th tubes contained pasteurized milk only. $100 \mu \mathrm{L}$ of a diluted overnight culture of E. fergusonii was added to test tubes 1-11 giving a final concentration of approx. $10^{5} \mathrm{CFU} / \mathrm{mL}$ in each tube. Tube 11 was E. fergusonii and milk only and tube 12 contained pasteurized milk only. All the test tubes were incubated at $37^{\circ} \mathrm{C}$ for $24 \mathrm{~h}$. Following incubation, the samples were serially diluted (1:10) in quarter strength Ringer's solutions and appropriate dilutions were plated on TSA plates. The plates were incubated at $37^{\circ} \mathrm{C}$ for $24 \mathrm{~h}$. The lowest concentration of the EO treatment that inhibited visible growth of the pathogen after incubation was taken as the MIC of the treatment. Triplicate samples were included for each treatment and the experiment was replicated 3 times.

\subsection{Antimicrobial Activity of Combined Essential Oils of Black Pepper Extract (BPE) and Cinnamon Extract (CE) against E. fergusonii}

The BPE and CE were used alone at the MIC and in combination at $\frac{1}{4}, \frac{1}{2}$ and $\frac{3}{4}$ MIC to determine the antimicrobial effectiveness against $E$. fergusonii during fermentation (Table 1). Milk samples were inoculated with $1 \%$ each of a mixed culture $(v / v)$ of L. delbrueckii subspecies bulgaricus and S. thermophilus (LAB). $100 \mu \mathrm{L}$ of a diluted overnight culture of E. fergusonni was added to all the 6 tubes to give a final concentration of approx. $10^{5} \mathrm{CFU} / \mathrm{mL}$. Sets of the test tubes were then incubated for $24 \mathrm{~h}$ at $25^{\circ} \mathrm{C}$ or $43^{\circ} \mathrm{C}$. Growth control tubes (Tube 1) with inoculum but without the spice extracts were included in each experiment. Viable counts during growth were enumerated at $0,2,4,6,8,10,12$ and $24 \mathrm{~h}$. 
The samples were subsequently stored at $25^{\circ} \mathrm{C}$ for a further $120 \mathrm{~h}$ and survival of the bacterium during storage was evaluated every $24 \mathrm{~h}$ until termination of storage. Each set of treatment and test was carried out in triplicate.

Table 1. Concentrations of black pepper extract (BPE) and cinnamon extract (CE) were evaluated for antimicrobial effects against $E$. fergusonii.

\begin{tabular}{ccccc}
\hline Tube No. & BPE conc. $(\%)$ & CE conc. $(\%)$ & MIC of BPE & MIC of CE \\
\hline 1 & 0 & 0 & 0 & 0 \\
2 & 0.5 & 0 & 1 & 0 \\
3 & 0.125 & 0.1875 & $\frac{1}{4}$ & $\frac{3}{4}$ \\
4 & 0.25 & 0.125 & $\frac{1}{2}$ & $\frac{1}{2}$ \\
5 & 0.375 & 0.0625 & $\frac{3}{4}$ & $\frac{1}{4}$ \\
6 & 0 & 0.25 & 0 & 1 \\
\hline
\end{tabular}

For the post-contamination study, a set of samples was inoculated with $1 \%$ each of mixed culture $(v / v)$ culture of L. delbrueckii subspecies bulgaricus and S. thermophilus (LAB) only. The sets were incubated at $25{ }^{\circ} \mathrm{C}$ or $43{ }^{\circ} \mathrm{C}$ for $24 \mathrm{~h}$. Post-fermentation, $2-3 \times 10^{5}$ $\mathrm{CFU} / \mathrm{mL}$ stationary phase of $E$. fergusonii was added to each sample. The contaminated samples were then treated with combined BPE with CE shown in Table 1. Each treatment was stored at $25^{\circ} \mathrm{C}$ for $120 \mathrm{~h}$. Viable counts for E. fergusonii were determined by decimal serial dilution in quarter strength Ringers and plating $100 \mu \mathrm{L}$ on VRBA at $0,24,48,72,120$, $144 \mathrm{~h}$ during storage.

\section{8. $\mathrm{pH}$ Measurement}

The $\mathrm{pH}$ of the samples was measured with a Mettler Toledo Delta $320 \mathrm{pH}$ meter, at room temperature. Readings were taken before inoculation (negative control), immediately after inoculation $(T=0)$ and then at every sampling point.

\subsection{Statistical Analysis}

All experiments were performed in triplicate. The data were expressed as the mean $\pm \mathrm{SD}$. One way ANOVA was used to analyse all the treatments of BPE and/or $\mathrm{CE}$ and the control. When the results were significant, two-way ANOVA was used to analyse the interactions between treatments and time. Prism Graph Pad (USA), version 9.0 was used for the statistical analysis.

\section{Results}

\subsection{Effect of Combined BPE and CE on Growth of E. fergusonii and Change in $p H$ of Milk} Fermented at $25^{\circ} \mathrm{C}$

Black pepper and cinnamon extracts were assessed singly and in combination with each other in fermenting/fermented full cream pasteurized milk to determine their effect on E. fergusonii. Figure $1 \mathrm{~A}$ shows the growth curves of E. fergusonii incubated at $25^{\circ} \mathrm{C}$ in the presence of various concentrations of BPE incorporated together with $\mathrm{CE}$. The result shows that $E$. fergusonii grew in the control sample and it increased from the initial $10^{5} \mathrm{CFU} / \mathrm{mL}$ to $10^{9} \mathrm{CFU} / \mathrm{mL}$ during fermentation by the lactic acid bacteria at $25^{\circ} \mathrm{C}$ (Figure $1 \mathrm{~A}$ ). The counts in the samples treated with the spice extracts varied according to the concentrations but all treatments resulted in significantly lower counts than the control $(p<0.05)$. The most potent combination was $0.375 \%$ BPE (three-quarters MIC) combined with $0.0625 \% \mathrm{CE}$ (one-quarter MIC) with the viable cell counts of approx. $10^{7} \mathrm{CFU} / \mathrm{mL}, 2 \log$ units lower than the counts in the control samples. In the samples with either BPE or CE alone, the bacterium grew to approx. $10^{8} \mathrm{CFU} / \mathrm{mL}$. 
The viable cell counts of lactic acid bacteria were determined at both fermentation temperatures. S. thermophilus increased in all the samples from $10^{6} \mathrm{CFU} / \mathrm{mL}$ to approximately $10^{8} \mathrm{CFU} / \mathrm{mL}$ and $10^{9} \mathrm{CFU} / \mathrm{mL}$ at $25^{\circ} \mathrm{C}$ and $43^{\circ} \mathrm{C}$ respectively and remained consistent until the end of fermentation. L. delbrueckii subspecies bulgaricus increased to $10^{9} \mathrm{CFU} / \mathrm{mL}$ at $24 \mathrm{~h}$ at both temperatures showing no inhibition of both $\mathrm{S}$. thermophilus and L. delbrueckii subspecies bulgaricus in the presence of the EOs (Figures S1-S12).

The initial $\mathrm{pH}$ of the pasteurized milk was $6.8( \pm 0.1)$ but all the samples showed an immediate slight reduction in $\mathrm{pH}$ in the milk after incorporation of the EO (Figure 1B). During the fermentation, the $\mathrm{pH}$ declined from the initial $6.8( \pm 0.1)$ to approximate $\mathrm{pH}$ $5.3-5.8( \pm 0.2)$ after $10 \mathrm{~h}$ of incubation and thereafter to 5.0-5.5 $( \pm 0.2)$ in all the samples. The highest $\mathrm{pH}$ reduction was in the sample containing a combination of $0.0625 \% \mathrm{CE}$ with $0.375 \% \mathrm{BPE}$ while the least $\mathrm{pH}$ reduction was observed at $0.5 \%$ BPE (alone). Reduction in $\mathrm{pH}$ was rapid in all the samples between $6-10 \mathrm{~h}$ of fermentation, which corresponded to the decrease in the growth rate of the pathogen.
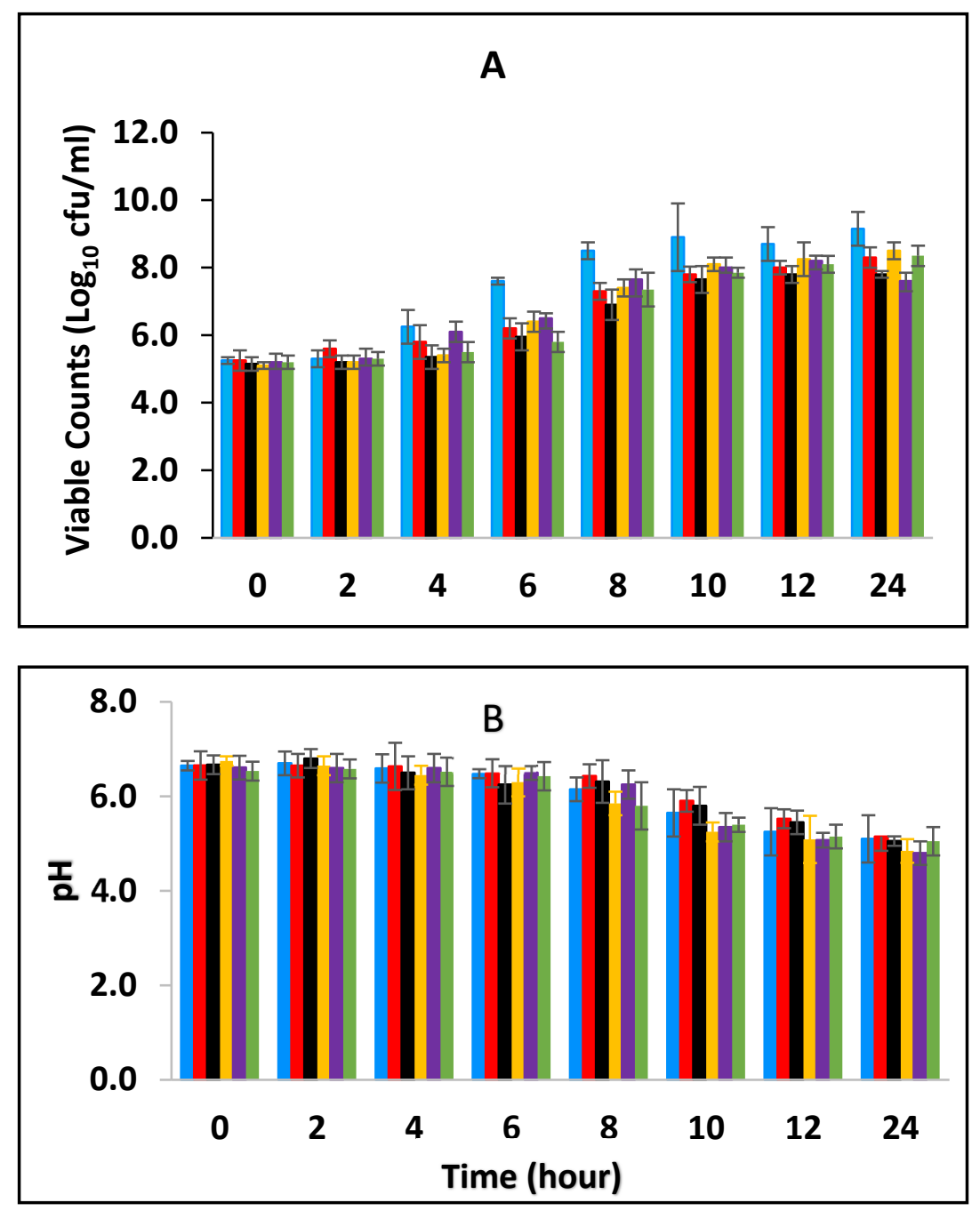

Figure 1. Growth of E. fergusonii (A) and change in $\mathrm{pH}(\mathbf{B})$ in fermenting milk in the presence of essential oils of black pepper (BPE) and cinnamon extracts (CE) at different concentrations at $25^{\circ} \mathrm{C}$ for $24 \mathrm{~h}$. Concentrations are in $\%(w / v)$, values are the mean of three individual replicates (means \pm

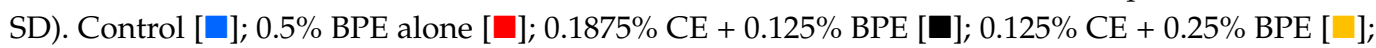
$0.0625 \%$ CE + 0.375\% BPE [ $\square] ; 0.25 \%$ CE alone [ $[$ ]. 
3.2. Effect of Various Concentrations of BPE and CE on the Growth of E. fergusonii and Change in $\mathrm{pH}$ of Milk Fermented at $43{ }^{\circ} \mathrm{C}$

Figure 2 shows the effect of BPE when incorporated together with $\mathrm{CE}$ on the growth of E. fergusonii and changes in the $\mathrm{pH}$ of full cream milk fermented at $43^{\circ} \mathrm{C}$. The results show that E. fergusonii counts increased in the control sample to approx. $10^{10} \mathrm{CFU} / \mathrm{mL}$ after $12 \mathrm{~h}$ of fermentation then declined slightly at $24 \mathrm{~h}$ (Figure 2A). Statistical analysis showed a highly significant $(p<0.001)$ difference between the EO treatments after $8 \mathrm{~h}$ and fermentation time also had a significant effect $(p<0.05)$. The most effective combination was $0.125 \%$ BPE (one-quarter MIC) with $0.1875 \%$ CE (three-quarter MIC) and the bacterium was not detected after $8 \mathrm{~h}$ of incubation. After ten and twelve hours of fermentation, the bacterium was reduced to undetectable levels in the samples with a combination of $0.25 \%$ BPE (one-half MIC) with $0.125 \%$ CE (one-half MIC); and 0.375\% BPE (three-quarter MIC) with $0.25 \%$ CE (one-quarter MIC) respectively. With $0.25 \% \mathrm{CE}$, growth of approximately $2 \log$ units was observed in the initial $8 \mathrm{~h}$ of fermentation and then growth halted. The presence of $0.5 \%$ BPE resulted in an increase of approximately $3 \log$ cycles in the same period of fermentation and reached $1 \log$ unit less than the control sample at $24 \mathrm{~h}$ of fermentation.

The $\mathrm{pH}$ was lowest in the samples without the addition of spices ( $\mathrm{pH} 4.3-4.8 \pm 0.2$ ), while the highest $\mathrm{pH}$ was observed in milk containing $0.25 \% \mathrm{CE}$ alone of $\mathrm{pH} 5.2 \pm 0.2$ after $24 \mathrm{~h}$ (Figure $2 \mathrm{~B}$ ). In general, the $\mathrm{pH}$ declined from the initial $6.8( \pm 0.1)$ to average of $\mathrm{pH} 5.8$ $( \pm 0.2)$ after $10 \mathrm{~h}$ of incubation and then to 5.0 at $24 \mathrm{~h}$.
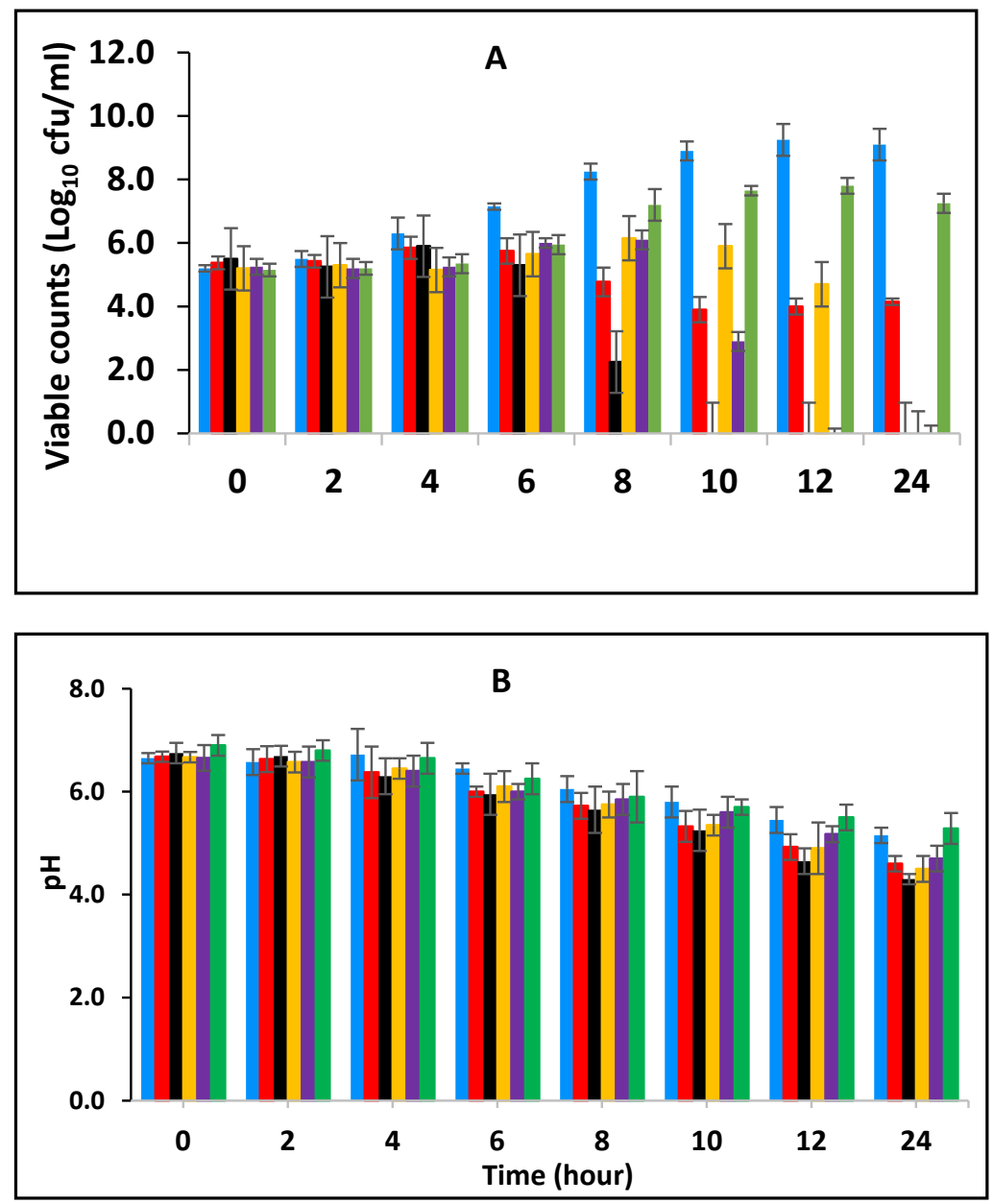

Figure 2. Growth of E. fergusonii (A) and change in $\mathrm{pH}(\mathbf{B})$ in fermenting milk in the presence of essential oils of black pepper (BPE) and cinnamon extracts (CE) at different concentrations at $43{ }^{\circ} \mathrm{C}$ for $24 \mathrm{~h}$. Concentrations are in $\%(w / v)$, values are the mean of three individual replicates (means \pm SD). Control [ $[$ ]; 0.5\% BPE alone [ $\square]$; 0.1875\% CE + 0.125\% BPE [ $]$ ]; 0.125\% CE + 0.25\% BPE [ ]; $0.0625 \%$ CE + 0.375\% BPE [ $[$ ] $0.25 \%$ CE alone [ $[$ ]. 
3.3. Survival of E. fergusonii in Fermented Milk during Storage at $25^{\circ} \mathrm{C}$ in Samples Treated with $B P E$ and $C E$

\subsubsection{Survival of E. fergusonii during Storage in Milk Fermented at $25^{\circ} \mathrm{C}$}

In this section, the effect of subsequent storage at $25^{\circ} \mathrm{C}$ on the survival of E. fergusonii in the milk fermented at $25^{\circ} \mathrm{C}$ in the presence of various concentrations of BPE and CE was determined (Figure 3A). Traditionally farmers add some spices during milk fermentation mainly for their aroma and flavour but also possibly to control the growth of any pathogens in the milk. Milk is fermented in the warmer part of the house $\left(25-30{ }^{\circ} \mathrm{C}\right)$ and after fermentation, the farmer stores the fermented milk at room temperature $\left(20-30{ }^{\circ} \mathrm{C}\right)$ for a period between three to five days before consumption [49]. L. delbrueckii subspecies bulgaricus and $S$. thermophilus were incorporated with BPE together with CE and subsequently, the samples were maintained at $25^{\circ} \mathrm{C}$ (Figure 3) simulating African room temperatures and practice for both fermentation and storage of the product which effectively extended the fermentation time. Figure 3 shows that the treatments which included both BPE and CE had a highly significant effect $(p<0.001)$ on E. fergusonii and the bacterium was not detected after $24 \mathrm{~h}$ of storage in the samples containing $0.375 \%$ BPE combined with $0.0625 \% \mathrm{CE}$. In the samples containing $0.25 \% \mathrm{BPE}$ combined with $0.125 \% \mathrm{CE}$ the organism was not detected after $48 \mathrm{~h}$ of storage. There was also a significant interaction between treatment and storage time $(p<0.001)$.
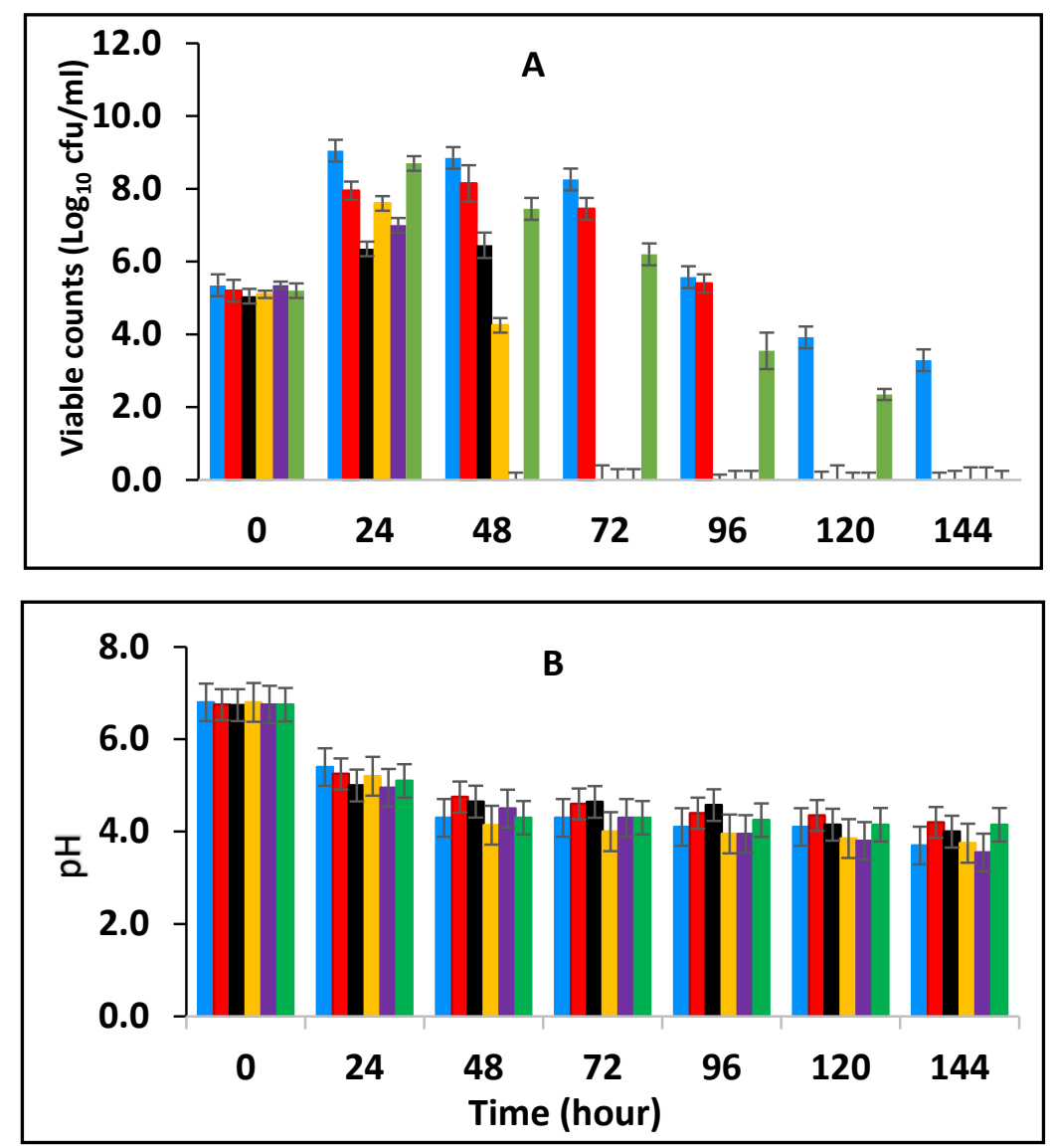

Figure 3. Survival of E. fergusonii (A) and change in $\mathrm{pH}$ (B) during storage at $25^{\circ} \mathrm{C}$ of milk fermented at $25^{\circ} \mathrm{C}$, in the presence of essential oils of black pepper (BPE) and cinnamon extracts (CE) at different concentrations for $24 \mathrm{~h}$. Concentrations are in $\%(w / v)$, values are the mean of three individual replicates (means $\pm \mathrm{SD}$ ). Control [ $\square] ; 0.5 \% \mathrm{BPE}$ alone [ $[\mathbf{\square} ; 0.1875 \% \mathrm{CE}+0.125 \% \mathrm{BPE}[\mathbf{\square}] ; 0.125 \% \mathrm{CE}$ $+0.25 \%$ BPE $[\square] ; 0.0625 \%$ CE + 0.375\% BPE [ $] ; 0.25 \%$ CE alone [ $]$ ].

At the point of storage, the $\mathrm{pH}$ values were between $\mathrm{pH} 5.0-5.4( \pm 0.2)$ (Figure 3B). The $\mathrm{pH}$ was approx. $5.0( \pm 0.2)$ in samples containing $0.375 \%$ BPE combined with $0.0625 \%$ 
$\mathrm{CE}$ and $\mathrm{pH} 5.2( \pm 0.2)$ in the control samples. Throughout the storage period, the $\mathrm{pH}$ of the samples continued to decline initially sharply, but later less rapidly. At $144 \mathrm{~h}$ of storage, the $\mathrm{pH}$ in the control samples was approx. $\mathrm{pH} 4.2 \pm 0.2$ and the samples with EOs also declined over this period suggesting the continued fermentation of the milk by lactic acid bacteria. However, the $\mathrm{pH}$ did not decline to the same extent in samples with a single EO.

\subsubsection{Survival of E. fergusonii during Storage in Milk Fermented at $43^{\circ} \mathrm{C}$}

Figure $4 \mathrm{~A}$ shows the effect of fermentation at $43^{\circ} \mathrm{C}$ for $24 \mathrm{~h}$ and subsequent storage at $25^{\circ} \mathrm{C}$ in the presence of spices, on the survival of E. fergusonii. During fermentation at $43{ }^{\circ} \mathrm{C}$ prior to storage, the bacterium was undetectable in samples containing, $0.125 \% \mathrm{BPE}$ with $0.1875 \%$ CE; $0.125 \%$ BPE with $0.1875 \%$ CE; $0.25 \%$ BPE with $0.125 \%$ CE and $0.375 \%$ BPE with $0.0625 \% \mathrm{CE}$. After storage at $25{ }^{\circ} \mathrm{C}$ for $144 \mathrm{~h}$, the bacterium was not detected in any of the samples. In samples with $0.5 \% \mathrm{BPE}$ and $0.25 \% \mathrm{CE}$, there was a rapid decline in the viable cell counts of the bacterium during storage at $25^{\circ} \mathrm{C}$ and it was not detected after $48 \mathrm{~h}$ of storage. In all, storage of milk fermented at $43^{\circ} \mathrm{C}$, co-inoculated with E. fergusonii resulted in a significant decrease of viable cells to undetectable levels over the 5-day storage period (Figure 4A). The inability of the E. fergusonii to maintain its viability correlates with the decline of the $\mathrm{pH}$ throughout storage (Figure 4B) from the initial $\mathrm{pH} 6.8$ to between 4.8 $( \pm 0.2)$ for samples containing $0.375 \%$ BPE combined with $0.0625 \% \mathrm{CE}$ and to $\mathrm{pH} 5.2( \pm 0.2)$ in the control samples. After $144 \mathrm{~h}$ of storage, the control samples and the samples with $0.25 \% \mathrm{CE}$ alone had the lowest $\mathrm{pH}$ (slightly below $\mathrm{pH} 4.0 \pm 0.2$ ) suggesting the continued fermentation of the milk by lactic acid bacteria.
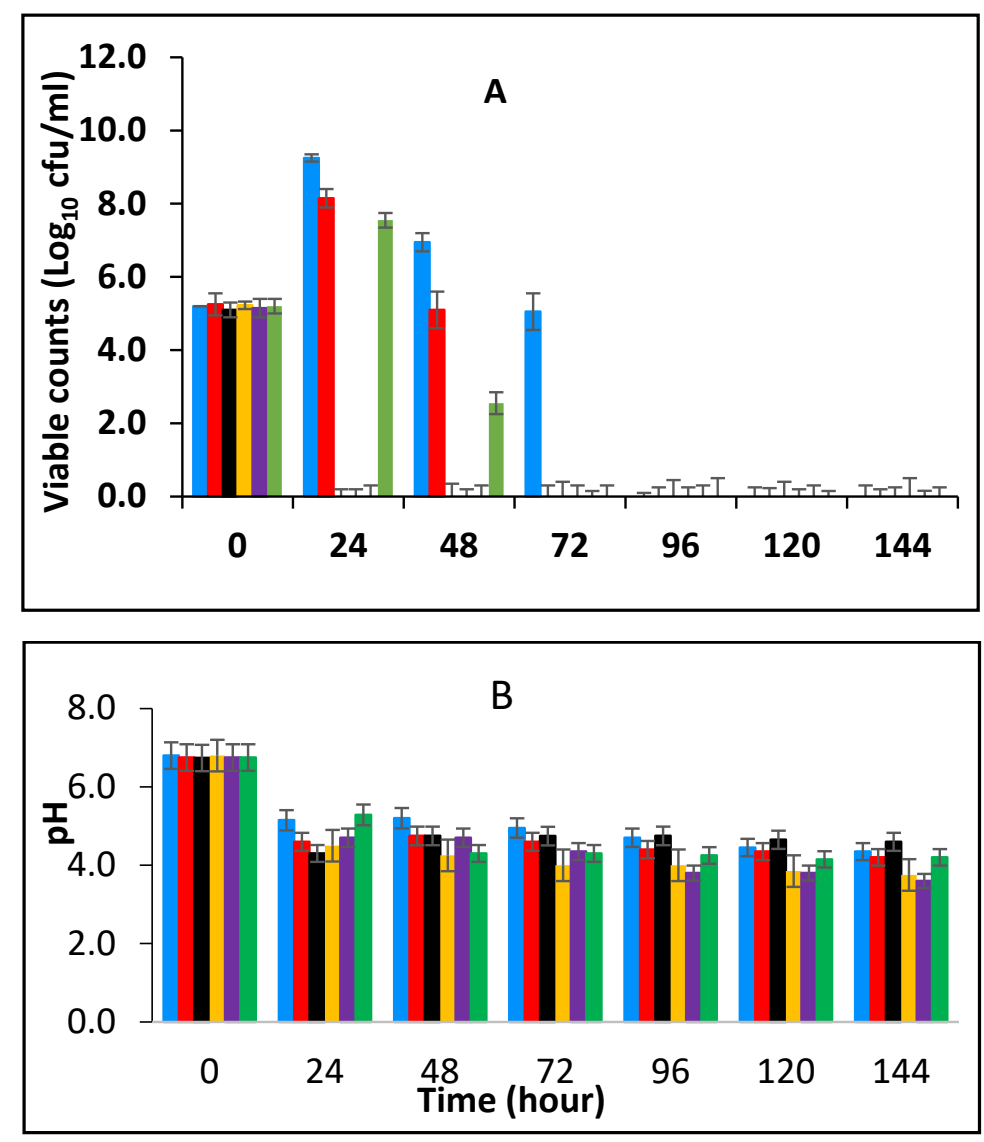

Figure 4. Survival of E. fergusonii (A) and change in $\mathrm{pH}(\mathbf{B})$ during storage at $25^{\circ} \mathrm{C}$ of milk fermented at $43^{\circ} \mathrm{C}$, in the presence of essential oils of black pepper (BPE) and cinnamon extracts (CE) at different concentrations for $24 \mathrm{~h}$. Concentrations are in $\%(w / v)$, values are the mean of three individual replicates (means $\pm \mathrm{SD}$ ). Control [ $\square] ; 0.5 \% \mathrm{BPE}$ alone [ $[\mathbf{\square} ; 0.1875 \% \mathrm{CE}+0.125 \% \mathrm{BPE}[\mathbf{\square}] ; 0.125 \% \mathrm{CE}$ $+0.25 \%$ BPE $[\square] ; 0.0625 \%$ CE + 0.375\% BPE [ $] ; 0.25 \%$ CE alone [ $]$ ]. 


\subsection{Post Fermentation Survival of E. fergusonii}

3.4.1. Survival of E. fergusonii Inoculated into Milk after Fermentation at $25^{\circ} \mathrm{C}$ and Subsequently Stored at $25^{\circ} \mathrm{C}$

Milk was fermented at $25^{\circ} \mathrm{C}$ and then inoculated with $10^{5} \mathrm{CFU} / \mathrm{mL}$ of stationary phase E. fergusonii (post-fermentation contamination) in addition to various combinations of BPE and CE of 0.5\% BPE alone; $0.125 \%$ BPE with $0.1875 \%$ CE; $0.25 \%$ BPE with $0.125 \%$ CE; $0.375 \%$ BPE with $0.0625 \% \mathrm{CE} ; 0.25 \% \mathrm{CE}$ alone as natural antimicrobials. A control sample without the spices was also included and all were stored at $25^{\circ} \mathrm{C}$ for 5 days (Figure $5 \mathrm{~A}$ ). The samples containing both BPE and CE showed a significant reduction in E. fergusonii compared to the control $(p<0.05)$ and this was time-dependent. After $24 \mathrm{~h}$ of storage, the viable cell numbers declined from the initial $10^{5} \mathrm{CFU} / \mathrm{mL}$ to undetectable levels in the samples containing $0.375 \%$ BPE with $0.0625 \%$ CE indicating the effect of BPE as it was three-quarters of the combination. The results in Figure 5A show that the combination that was next most effective was $0.125 \%$ BPE with $0.1875 \% \mathrm{CE}$, as the bacterium was undetectable after $48 \mathrm{~h}$ of storage. However, in samples with EO alone $(0.5 \%$ BPE or $0.25 \%$ $\mathrm{CE}$ ), the bacterium took longer to demise and was not recovered after 3 and 4 days of storage which was similar to the control.
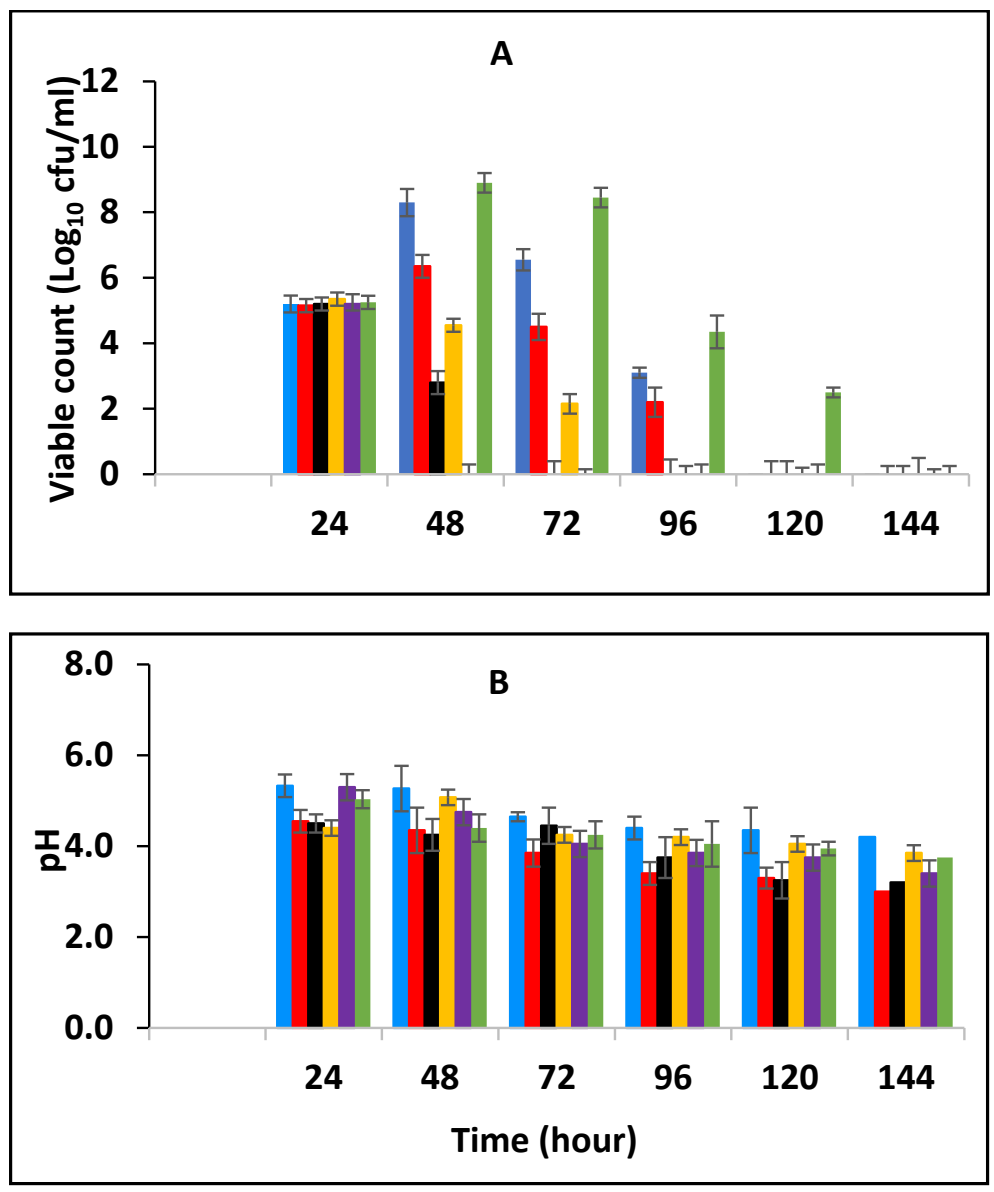

Figure 5. Survival of E. fergusonii (A) and change in $\mathrm{pH}(\mathbf{B})$ in the presence of essential oils of black pepper (BPE) and cinnamon extracts (CE) during storage at $25{ }^{\circ} \mathrm{C}$ of yoghurt fermented at $25^{\circ} \mathrm{C}$ for $24 \mathrm{~h}$. The EOs were added at different concentrations post milk fermentation. Concentrations are in $\%(w / v)$, values are the mean of three individual replicates (means \pm SD). Control [ $] ; 0.5 \%$ BPE

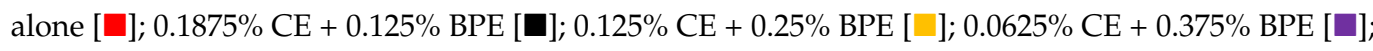
$0.25 \%$ CE alone [ $\square$ ].

The effect of $\mathrm{pH}$ is presented in Figure 5B. The initial $\mathrm{pH}$ at the point of storage was $5.1( \pm 0.2)$. During the storage period, the $\mathrm{pH}$ of the samples declined in all the samples 
by approximately $1.2-1.5 \mathrm{pH}$ units in all the other samples. The highest reduction was when $\mathrm{CE}$ was applied alone. The action of the bacterial enzyme on lactose results in the production of lactic acids and acetaldehyde which reduced the $\mathrm{pH}$ and contributed to the demise of E. fergusonii during storage. The spices did not affect the growth of LAB significantly but did reduce the rate of the $\mathrm{pH}$ decline of the fermenting milk.

3.4.2. Survival of E. fergusonii Inoculated into Milk after Fermentation at $43^{\circ} \mathrm{C}$ and Subsequently Stored at $25^{\circ} \mathrm{C}$

Milk was fermented at $43{ }^{\circ} \mathrm{C}$ and then inoculated with $10^{5} \mathrm{CFU} / \mathrm{mL}$ of stationary phase E. fergusonii (post-fermentation contamination) in addition to varied concentrations of BPE and CE then subsequently stored at $25^{\circ} \mathrm{C}$. Figure 6 showed that storage at $25^{\circ} \mathrm{C}$ resulted in a decrease of viable E. fergusonii cells to undetectable levels within $24 \mathrm{~h}$ of storage in the samples with the concentrations of $0.375 \% \mathrm{BPE}$ (three-quarters MIC) combined with $0.0625 \%$ CE (one-quarter MIC). Similarly, after $48 \mathrm{~h}$, viable cells were not detected in the samples with concentrations of $0.125 \%$ BPE with $0.1875 \%$ CE or $0.25 \%$ BPE with $0.125 \%$. The viable cell population continued to decline to undetectable levels after $72 \mathrm{~h}$. The effect of $\mathrm{pH}$ during storage at $25^{\circ} \mathrm{C}$ after fermentation at $43^{\circ} \mathrm{C}$ is presented in Figure $6 \mathrm{~B}$. The initial $\mathrm{pH}$ was $\mathrm{pH} 5.2( \pm 0.2)$ and it declined in all the samples, however, fermentation without treatment with EOs had the lowest $\mathrm{pH}$.
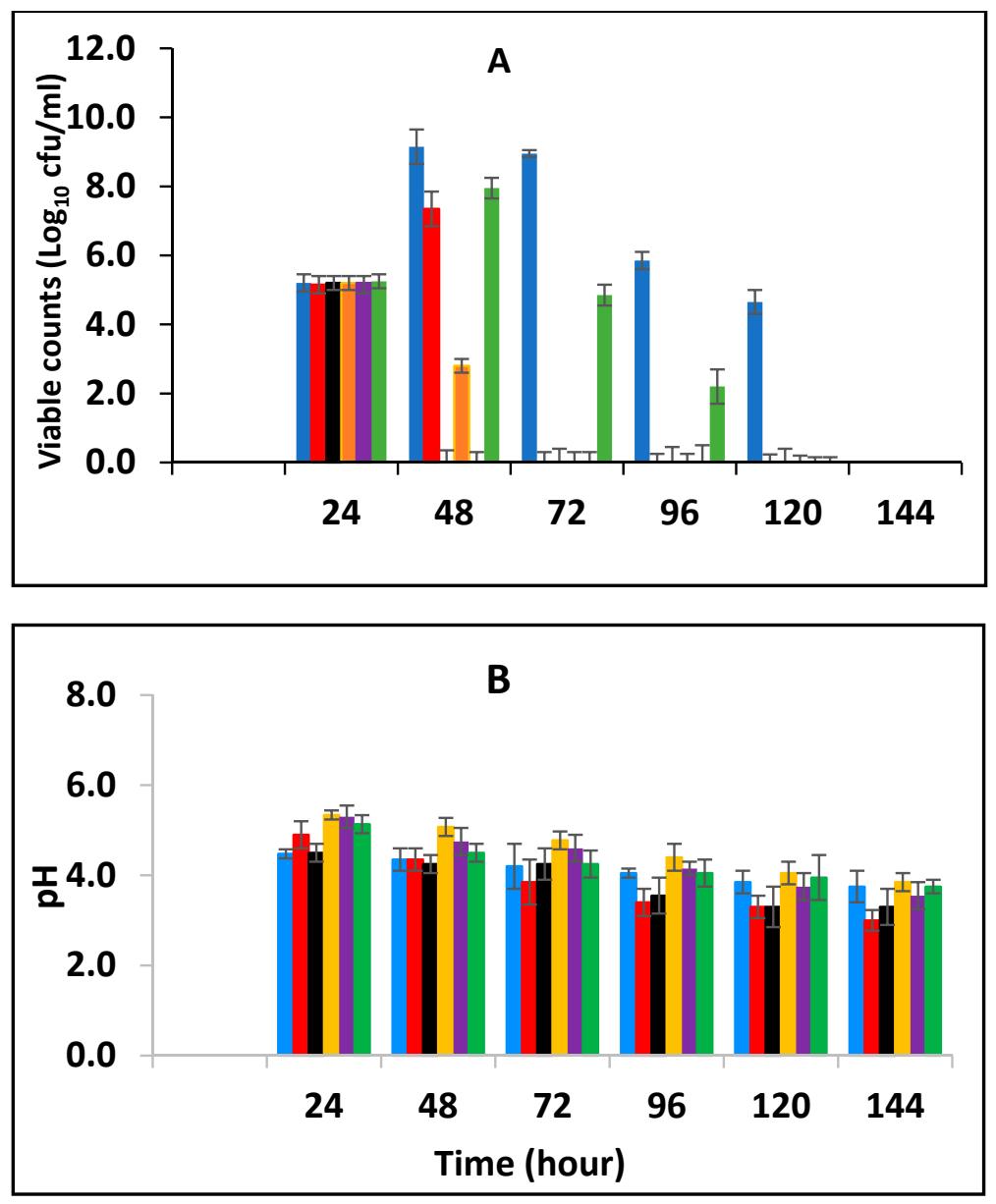

Figure 6. Survival of E. fergusonii (A) and change in $\mathrm{pH}(\mathbf{B})$ in the presence of essential oils of black pepper (BPE) and cinnamon extracts (CE) during storage at $25{ }^{\circ} \mathrm{C}$ of yoghurt fermented at $43{ }^{\circ} \mathrm{C}$ for $24 \mathrm{~h}$., The EOs were added at different concentrations post milk fermentation. Concentrations are in $\%(w / v)$, values are the mean of three individual replicates (means \pm SD). Control [ $] ; 0.5 \%$ BPE alone $[\square] ; 0.1875 \%$ CE + 0.125\% BPE [ $\mathbf{\square}] ; 0.125 \%$ CE + 0.25\% BPE [ $] ; 0.0625 \%$ CE + 0.375\% BPE [ $]$; $0.25 \%$ CE alone [ $\square$ ]. 


\section{Discussion}

In this study, we observed the effect of BPE combined with CE against E. fergusonii in full cream pasteurized milk fermented at $25^{\circ} \mathrm{C}$ to simulate ambient, African fermentation temperature, and at $43^{\circ} \mathrm{C}$, the industrial fermentation temperature. The higher fermentation temperature of $43{ }^{\circ} \mathrm{C}$ resulted in a more rapid decline in E. fergusonii than in milk fermented at $25^{\circ} \mathrm{C}$. The results in Figures 1 and 2 showed that the higher temperatures resulted in a lower $\mathrm{pH}$ due to the acid production during the growth of the lactic acid bacteria. It also showed that the EO did not affect acidification by the LAB at the higher temperature. At the lower temperature $\left(25^{\circ} \mathrm{C}\right)$, the $\mathrm{pH}$ reduction was less marked due to the slower growth of the LAB. At $43{ }^{\circ} \mathrm{C}$, the bacterium was completely inactivated after twenty-four hours of incubation whereas, at $25^{\circ} \mathrm{C}$, the pathogen was detected in all the treatments, although at counts lower than that of the control samples. A similar effect of fermentation temperature was reported by Visvalingam and Holley [50] on E. coli. The degree of cell reduction depended on the combination of concentrations of the EOs (Figures 1 and 2).

The MIC of BPE $(0.5 \%)$ and CE $(0.25 \%)$ against E. fergusonii are comparable with the value reported by Cava et al., [51] for the MIC of cinnamon extract $(0.31 \%)$ against E. coli in pasteurized milk. In this study, the effect on the viable counts in the samples treated with the spice extracts varied according to the concentrations. The combination of one-quarter fraction of MIC of BPE $(0.125 \%)$ to three-quarters of MIC of CE $(0.1875 \%)$ reduced the growth of E. fergusonii to a greater extent than the other combinations. The next most potent combination was $0.375 \%$ BPE (three-quarters MIC) combined with $0.0625 \%$ $\mathrm{CE}$ (one-quarter MIC). The results showed that cinnamon extract was enhanced by black pepper extract if the concentration of the cinnamon extract was three times the MIC of $\mathrm{BPE}$. These results suggest that $\mathrm{CE}$ and $\mathrm{BPE}$ in combination are effective EOs capable of improving the effectiveness of milk fermentation to inhibit E. fergusonii.

The results showed that the higher fermentation temperature resulted in a more marked reduction in cell numbers and reflected the reduction in $\mathrm{pH}$ of the medium due to lactic acid production. The addition of spices was an added stress on the cells and may have led to more inhibition at the higher temperature of $43^{\circ} \mathrm{C}$. Althair et al. [52] indicated that heat treatment had effects on the physicochemical properties of bacteria during mudafra cheese ripening. With emerging drug and acid-resistant microorganisms in recent years, natural antimicrobials that can act synergistically are crucial in controlling foodborne pathogens. Essential oils could serve as promising tools in enhancing food preservation and a similar conclusion was reached by Pavác et al. [53]. In this study, fermentation at African room temperature $\left(25^{\circ} \mathrm{C}\right)$ was not sufficient on its own to inhibit the bacterium as the $\mathrm{pH}$ was approx. 5 after $24 \mathrm{~h}$. Similarly, Ogwaro et al., [54] reported a rapid decline in the numbers of E. coli O157:H7, another drug-resistant bacterium, only when the $\mathrm{pH}$ had reached $\mathrm{pH} 4.4$ and below. In addition, post-fermentation contamination is a concern and this was apparent during the storage of the fermented milk at $25^{\circ} \mathrm{C}$ ( $3-5$ days). This work has shown that lactic fermentation in the presence of the EOs enhances the effect of acidification of the fermented milk and reduces the subsequent survival of E. fergusonii. The bacterium reached undetectable levels when the $\mathrm{pH}$ of the milk was still higher than $\mathrm{pH}$ 5.0. This suggests a synergetic reaction between the fermentation acids in combination with the EOs.

This work has shown that the addition of spice essential oils enhances the inhibition of the bacterium. Furthermore, according to Moon et al., [55], at low pH, the antimicrobial molecules bind better to the hydrophobic zone of the membrane, where they are diluted in the lipid phase, improving their activities on bacteria and fungi. In addition, to the temperature of fermentation, the effect of the combination of the spices showed higher antimicrobial activity compared to a single application (1 MIC) of both EOs. These findings may be useful for food applications, but their effect on the sensory quality of various foods needs to be studied. The effect of the combined concentrations had more impact at the higher fermentation temperature $\left(43^{\circ} \mathrm{C}\right)$ than at the lower fermentation temperature 
$\left(25^{\circ} \mathrm{C}\right)$ as seen in Figures 1 and 2. It is evident from these results that the combinations of the EOs had a greater impact than when the EOs were applied alone, suggesting additive activity. Moreover, where the amount of CE was higher than BPE, the inhibition increased. This is an indication that BPE acted as a facilitator by enhancing the activity of CE. Enhanced antimicrobial activity of EOs at the higher temperature could be due to an increased rate of cellular metabolism, growth and death. The increased inhibition at $43^{\circ} \mathrm{C}$, the higher temperature, could be also due to increased fluidity of the cytoplasmic membrane that occurs at warmer temperatures [56]. The results show that there was a positive association between antimicrobial concentration and microbial inhibition although this effect was variable.

The mode of action of cinnamaldehyde has been shown to be inhibition of amino acid decarboxylases in Enterobacter aerogenes [57,58] due to the carbonyl group binding to proteins, thus preventing the action of these decarboxylases. Hyidgaard et al. [59] reported that trans-cinnamaldehyde was capable of inhibiting E. coli and Salmonella by gaining access to the periplasm and inhibiting the activity of transmembrane ATPase. However, Helander et al. [60] found that trans-cinnamaldehyde was capable of inhibiting E. coli without gaining access to the periplasm as well as the deeper parts of the bacterial cell. In research conducted by Gill and Holley [61], increasing the concentration of cinnamaldehyde $(0.0136-0.1362 \%)$ was found to decrease ATPase activity of isolated cell membranes. This is consistent with the highest impact on the cells being observed at $0.1875 \% \mathrm{CE}$, which is higher than that tested by Gill and Holley [62]. The effect of the EOs depended on the composition of the mixture of the two EOs as well as the temperature of fermentation.

After fermentation, the samples were subsequently stored at $25^{\circ} \mathrm{C}$ and the effect of storage on E. fergusonni was observed. This assessment showed that microbial reduction was promoted by EOs during storage. Exposure time had a strong influence on microbial reduction, but also that such an effect was dependent on when the antimicrobial was added to the milk, either pre-fermentation or post-fermentation. When the antimicrobial was added post-fermentation and then stored, the EOs were more effective than when applied pre-fermentation. This suggests that for pathogen inactivation, and to achieve a certain microbial reduction, distinct exposure times to the EOs are required. This is also related to the $\mathrm{pH}$ of the sample. It was also observed that when adding the EOs post milk fermentation a faster inhibitory rate of inhibition occurred compared to adding the EOs to the milk pre-fermentation (Figures 3-6).

The effect of subsequent storage at $25^{\circ} \mathrm{C}$ on E. fergusonii showed that the effect was highest with the concentrations of $0.375 \% \mathrm{BPE}$ (three-quarters MIC) with $0.0625 \% \mathrm{CE}$ (onequarter MIC). This is contrary to the effect observed during fermentation, where the effect of the EOs were stronger at the combinations of the concentrations of $0.125 \% \mathrm{BPE}$ (onequarter MIC) with $0.1875 \%$ CE (three-quarters MIC) was highest. Patil et al. [63] reported that piperine, the major pungent component of black pepper can enhance the bioavailability of other drugs due to its low aqueous solubility and in fermented milk, where the casein has been broken down, provides better access to the cell membrane. Storage at $25^{\circ} \mathrm{C}$ was to simulate the ambient and storage temperature of traditional yoghurt in rural Africa. However, this temperature could also be considered a temperature abuse for storage because enteric bacteria can grow at this temperature which could result in the growth of foodborne pathogens and increase the risk of illness from foodborne diseases. It was observed that increased storage time of the fermented milk at $25^{\circ} \mathrm{C}$ resulted in a further reduction in $\mathrm{pH}$ of the fermented milk and in combination with BPE and CE limited the survival of the E. fergusonii.

Several important variables were observed when EOs were applied in the fermenting full cream milk assay. It was evident that the antimicrobial activities of EOs were affected by the contact time of the oils on the bacterium and the concentration required to achieve the same degree of inhibition. These two variables interacted with each other. The results showed that incorporation of EOs into yoghurt (post-fermentation) was more effective in inhibiting E. fergusonii, whereas application in pre-fermentation of milk resulted in a lower 
inhibitory effect. When BPE was applied in combination with CE to lactic fermenting milk, reduced cell counts were observed during storage rather than during fermentation. This could mean that the effect of $\mathrm{pH}$ had already weakened the cells thus adding another stress factor such as the EOs was able to penetrate the cells causing rapid death.

The third factor in the extent of the inactivation of the bacterium was $\mathrm{pH}$. The effect of $\mathrm{pH}$ and lactic acid concentration play a crucial role in inhibiting Enterobacteriaceae in yoghurt. At low $\mathrm{pH}$, yeasts and moulds are an issue particularly if fruits are added. The addition of whole unextracted spices by farmers into yoghurts could also pose risks of contamination and spoilage so for this reason spice extract could be a better alternative for farmers. As the $\mathrm{pH}$ declined to 5.2 and below, the antimicrobial effects of the EOs became more pronounced. The higher inhibition of combined spice extracts in full cream pasteurized milk at $43{ }^{\circ} \mathrm{C}$ rather than at $25^{\circ} \mathrm{C}$ can be attributed to the influence of low $\mathrm{pH}$. Fitzgerald et al. [64] reported the effect of $\mathrm{pH}$ when they assessed the antimicrobial activity of vanillin in apple juice. The antibacterial activity of cinnamon bark extract may be attributed to the high presence of active compounds like cinnamaldehyde and other minor components such as alkaloids, tannins, terpenes and saponins which may act additively or synergistically in inhibiting bacterial growth, causing cell structural damage and leakage of cellular contents and cinnamaldehyde also interferes with electron transfer in cells. Yossa et al. [65] used scanning and transmission electron microscopy of cinnamon oil-treated bacterial cells and reported that there was cell structural damage and leakage of cellular content.

While it is desirable to add concentrations that can inhibit the bacteria rapidly in fermenting/fermented milk, this will be dependent upon the organoleptic acceptability of cinnamon bark or black pepper as their EOs have strong flavours. The synergistic effects of the two spices with each other and with fermentation acids on E. fergusonii should be exploited to optimize the concentration required to achieve the desired antibacterial effect without adversely affecting the organoleptic acceptability of the fermented milk. Thus, the use of combined technology could produce fermented foods of acceptable sensory quality and microbial safety. Furthermore, a good method of encapsulation of the EOs could be a solution to the use of natural antimicrobials of plant origin whilst minimizing organoleptic impact. It could be a practical way to enhance the microbiological safety of this traditional yoghurt produced by rural farmers.

Supplementary Materials: The following are available online at https:/ /www.mdpi.com/article/ $10.3390 /$ foods10112847/s1, Figure S1. Growth curves of L. delbrueckii subspecies bulgaricus in fermenting milk in the presence of essential oils of black pepper (BPE) and cinnamon extracts (CE) at different concentrations at $25^{\circ} \mathrm{C}$ for $24 \mathrm{~h}$. Concentrations are in $\%(w / v)$, values are the mean of three individual replicates (means $\pm \mathrm{SD}$ ). Figure S2. Growth curves of L. delbrueckii subspecies bulgaricus in fermenting milk in the presence of essential oils of black pepper (BPE) and cinnamon extracts (CE) at different concentrations at $43{ }^{\circ} \mathrm{C}$ for $24 \mathrm{~h}$. Concentrations are in $\%(w / v)$, values are the mean of three individual replicates (means $\pm \mathrm{SD}$ ). Figure S3. Growth of L. delbureckii subspecies bulgaricus in fermenting milk in the presence of essential oils of black pepper (BPE) and cinnamon extracts (CE) at different concentrations during storage at $25^{\circ} \mathrm{C}$ after fermentation at $25^{\circ} \mathrm{C}$ for $24 \mathrm{~h}$. Concentrations are in $\%(w / v)$, values are the mean of three individual replicates (means $\pm \mathrm{SD})$. Figure S4. Growth of L. delbrueckii subspecies bulgaricus in fermenting milk in the presence of essential oils of black pepper (BPE) and cinnamon extracts (CE) at different concentrations during storage at $25^{\circ} \mathrm{C}$ after fermentation at $43^{\circ} \mathrm{C}$ for $24 \mathrm{~h}$. Concentrations are in $\%(w / v)$, values are the mean of three individual replicates (means $\pm \mathrm{SD}$ ). Figure S5. Growth of L. delbrueckii subspecies bulgaricus during subsequent storage at $25^{\circ} \mathrm{C}$ of the milk fermented at $25^{\circ} \mathrm{C}$ for $24 \mathrm{~h}$ subsequently incorporated with black pepper extract (BPE) combined with cinnamon extract (CE) at different concentrations. Concentrations are in $\%(w / v)$, values are the mean of three individual replicates (means $\pm \mathrm{SD}$ ). Figure S6. Growth of L. delbrueckii subspecies bulgaricus during subsequent storage at $25^{\circ} \mathrm{C}$ of the milk fermented at $43^{\circ} \mathrm{C}$ for $24 \mathrm{~h}$ subsequently incorporated with black pepper extract (BPE) combined with cinnamon extract (CE) at different concentrations. Concentrations are in $\%(w / v)$, values are the mean of three individual replicates (means $\pm \mathrm{SD}$ ). Figure S7. Growth of S. thermophilus in fermenting milk in the 
presence of essential oils of black pepper (BPE) and cinnamon extracts (CE) at different concentrations at $25{ }^{\circ} \mathrm{C}$ for $24 \mathrm{~h}$. Concentrations are in $\%(w / v)$, values are the mean of three individual replicates (means \pm SD). Figure S8. Growth of $S$. thermophilus in fermenting milk in the presence of essential oils of black pepper (BPE) and cinnamon extracts (CE) at different concentrations at $43^{\circ} \mathrm{C}$ for $24 \mathrm{~h}$. Concentrations are in $\%(w / v)$, values are the mean of three individual replicates (means \pm SD). Figure S9. Growth of $S$. thermophilus in fermenting milk in the presence of essential oils of black pepper (BPE) and cinnamon extracts (CE) at different concentrations fermented at $25^{\circ} \mathrm{C}$ for $24 \mathrm{~h}$. Concentrations are in $\%(w / v)$, values are the mean of three individual replicates (means \pm SD). Figure S10. Growth of $S$. thermophilus in fermenting milk in the presence of essential oils of black pepper (BPE) and cinnamon extracts (CE) at different concentrations during storage at $25^{\circ} \mathrm{C}$ after fermentation at $43^{\circ} \mathrm{C}$ for $24 \mathrm{~h}$. Concentrations are in $\%(w / v)$, values are the mean of three individual replicates (means $\pm \mathrm{SD}$ ). Figure S11. Survival of $S$. thermophilus during subsequent storage at $25^{\circ} \mathrm{C}$ of the milk fermented at $25^{\circ} \mathrm{C}$ for $24 \mathrm{~h}$ subsequently incorporated with black pepper extract (BPE) combined with cinnamon extract (CE) at different concentrations. Concentrations are in \% $(w / v)$, values are the mean of three individual replicates (means $\pm \mathrm{SD}$ ). Figure S12. Survival S. thermophilus during subsequent storage at $25^{\circ} \mathrm{C}$ of the milk fermented at $43{ }^{\circ} \mathrm{C}$ for $24 \mathrm{~h}$ then incorporated with black pepper (BPE) and cinnamon extracts (CE) at different concentrations. Concentrations are in $\%$ $(w / v)$, the mean of three individual replicates (means $\pm \mathrm{SD}$ ).

Author Contributions: B.A.O. performed the methodology and wrote the original draft. H.G. and B.A.O. were the main persons responsible for planning the experiments and interpretation of the data; H.G., B.A.O., E.A.O. and D.J.H. were involved in the editing, reviewing and preparation of the manuscript. All authors have read and agreed to the published version of the manuscript.

Funding: This research received no external funding, but we would like to thank the Government of South Sudan for facilitating Betty Ogwaro through paying her monthly salaries through the study period and accepting her to take time off her duties to carry on the research.

Data Availability Statement: The data presented in this study are openly available.

Acknowledgments: We would like to acknowledge the contributions of Mohammed Ibrahim for facilitating the collection of spice samples from Iraq; Cecilya Odong and Sam Swingler for the graphic abstract design and the technical staff in the Microbiology laboratory for their technical support.

Conflicts of Interest: The authors declare no conflict of interest.

\section{References}

1. Farmer, J.J., 3rd; Fanning, G.R.; Davis, B.R.; O’hara, C.M.; Riddle, C.; Hickman-Brenner, F.W.; Asbury, M.A.; Lowery, V.A., 3rd; Brenner, D.J. Escherichia fergusonii and Enterobacter taylorae, two new species of Enterobacteriaceae isolated from clinical specimens. J. Clin. Microbiol. 1985, 21, 77-81. [CrossRef]

2. Touchon, M.; Hoede, C.; Tenaillon, O.; Barbe, V.; Baeriswyl, S.; Bidet, P.; Bingen, E.; Bonacorsi, S.; Bouchier, C.; Bouvet, O.; et al. Organised genome dynamics in the Escherichia coli species results in highly diverse adaptive paths. PLoS Genet. 2009, 5, e1000344. [CrossRef] [PubMed]

3. Rimoldi, M.G.; Moeller, R.B. Escherichia fergusonii associated with pneumonia in a beef cow. J. Vet. Med. 2013, $2013,829532$. [CrossRef] [PubMed]

4. Savini, V.; Catavitello, C.; Talia, M.; Manna, A.; Pompetti, F.; Favaro, M.; Fontana, C.; Febbo, F.; Balbinot, A.; Di Berardino, F.; et al Multidrug-resistant Escherichia fergusonii: A case of acute cystitis. J. Clin. Microbiol. 2008, 46, 1551-1552. [CrossRef] [PubMed]

5. Funke, G.; Hany, A.; Altwegg, M. Isolation of Escherichia fergusonii from four different sites in a patient with pancreatic carcinoma and cholangiosepsis. J. Clin. Microbiol. 1993, 31, 2201-2203. [CrossRef] [PubMed]

6. Bain, M.S.; Green, C.C. Isolation of Escherichia fergusonii in cases clinically suggestive of Salmonellosis. Vet. Rec. $1999,144,511$. [PubMed]

7. Hariharan, H.; Lopez, A.; Conboy, G.; Coles, M.; Muirhead, T. Isolation of Escherichia fergusonii from the faeces and internal organs of a goat with diarrhoea. Can. Vet. J. 2007, 48, 630-631.

8. Herráez, P.; Rodríguez, A.F.; Espinosa De Los Monteros, A.; Acosta, A.B.; Jaber, J.R.; Castellano, J.; Castro, A. Fibrino-necrotic typhlitis caused by Escherichia fergusonii in ostriches (Struthio camelus). Avian Dis. 2005, 49, 167-169. [CrossRef]

9. Saad, N.M.; Sabreen, M.S.; Amin, W.F.; Gendi, M.K. Prevalence of Escherichia albertii and other Escherichia species in raw milk and some dairy products in Assiut City, Egypt. J. Am. Sci. 2012, 8, 333-341.

10. Glover, B.; Wentzel, J.; Jenkins, A.; Van Vuuren, M. The first report of Escherichia fergusonii isolated from non-human primates, in Africa. One Health 2017, 3, 70-75. [CrossRef]

11. Adesina, T.; Nwinyi, O.; De, N.; Akinnola, O.; Omonigbehin, E. First detection of carbapenem-resistant Escherichia fergusonii strains harbouring beta-lactamase genes from clinical samples. Pathogens 2019, 8, 164. [CrossRef] 
12. Boniece, J.R.; Mallmann, W.1. The optimum incubation temperature for the primary isolation of coliform organisms. J. (Am. Water Work. Assoc.) 1950, 42, 155-160. [CrossRef]

13. Sherwood, H.P.; Clegg, L.F.L. Further studies of incubation at $44^{\circ} \mathrm{C}$ : As a test for 'faecal coli'. Epidemiol. Infect. 1942, $42,45-54$. [CrossRef] [PubMed]

14. Ingle, D.J.; Clermont, O.; Skurnik, D.; Denamur, E.; Walk, S.T.; Gordon, D.M. Biofilm formation by and thermal niche and virulence characteristics of Escherichia spp. Appl. Environ. Microbiol. 2011, 77, 2695-2700. [CrossRef]

15. Dirar, H.A. The Indigenous Fermented Foods of the Sudan: A Study in African Food and Nutrition; Cambridge University Press: Cambridge, UK, 1993.

16. Benkerroom, N. Traditional fermented foods of North African countries: Technology and food safety challenges with regard to microbiological risks. Compr. Rev. Food Sci. Food Saf. 2013, 12, 54-89. [CrossRef]

17. Agyei, D.; Owusu-Kwarteng, J.; Akabanda, F.; Akomea-Frempong, S. Indigenous African fermented dairy products: Processing Technology, Microbiology, and Health Benefits. Crit. Rev. Food Sci. Nutr. 2020, 60, 991-1006. [CrossRef] [PubMed]

18. Misihairabgwi, J.; Cheikhyoussef, A. Traditional fermented foods and beverages of Namibia. J. Ethn. Foods 2017, 4, 145-153 [CrossRef]

19. Abdalla, M.O.M.; Ahmed, A.N.S.Z. Evaluation of microbiological quality of Sudanese fermented dairy product 'mish' during storage. Adv. J. Food Sci. Technol. 2010, 2, 155-158.

20. Shelef, L.A. Antimicrobial effects of spices. J. Food Saf. 1984, 6, 29-44. [CrossRef]

21. Schelz, Z.; Molnar, J.; Hohmann, J. Antimicrobial, and antiplasmid activities of essential oils. Fitoterapia 2006, 77, 279-285. [CrossRef]

22. World Health Organization (WHO). The world traditional medicines situation. In Traditional Medicines: Global Situation, Issues and Challenges; WHO: Geneva, Switzerland, 2011; Volume 3, pp. 1-14.

23. Azzouz, M.A.; Bullerman, L.B. Comparative antimycotic effects of selected herbs, spices, plant components and commercial antifungal agents. J. Food Prot. 1982, 45, 1298-1301. [CrossRef] [PubMed]

24. Negi, P.S. Plant extracts for the control of bacterial growth: Efficacy, stability, and safety issues for food application. Int. J. Food Microbiol. 2012, 156, 7-17. [CrossRef] [PubMed]

25. Tajkarimi, M.M.; Ibrahim, S.A.; Cliver, D.O. Antimicrobial herb and spice compounds in food. Food Control 2010, 21, 1199-1218. [CrossRef]

26. Peter, K.V. Handbook of Herbs and Spices; Woodhead Publishing Limited: Cambridge, UK, 2001; Volume 1, ISBN 978-1-85573-562-0.

27. Ahmad, N.; Fazal, H.; Abbasi, B.H.; Farooq, S.; Ali, M.; Khan, M.A. Biological role of Piper nigrum L. (Black pepper): A review. Asian Pac. J. Trop. Biomed. 2012, 2, S1945-S1953. [CrossRef]

28. Shahidi, F.; Ambigaipalan, P. Phenolics and polyphenolics in foods, beverages, and spices: Antioxidant activity and health effects-A review. J. Funct. Foods 2015, 18, 820-897.

29. Chaudhry, N.M.; Tariq, P. Bactericidal activity of black pepper, bay leaf, aniseed, and coriander against oral isolates. Pak. J. Pharm. Sci. 2006, 19, 214-218.

30. Pie, H.; Xue, L.; Tang, M.; Kuang, S.; Wang, L.; Ma, X.; Cai, X.; Li, Y.; Zhao, M.; Peng, A.; et al. Alkaloids from Black Pepper (Piper nigrum L.) Exhibit anti-inflammatory activity in murine macrophages by inhibiting activation of NF-kB Pathway. J. Agric. Food Chem. 2020, 68, 2406-2417. [CrossRef]

31. Rani, S.S.; Saxena, N.; Udaysree, N. Antimicrobial activity of Black Pepper (Piper nigrum L.). Glob. J. Pharmacol. 2013, 7, 87-90.

32. Nagavekar, N.; Singhal, R.S. Enhanced extraction of oleoresin from Piper nigrum by supercritical carbon dioxide using ethanol as a co-solvent and its bioactivity profile. J. Food Process. Eng. 2018, 41, e12670. [CrossRef]

33. Khan, M.; Hanif, M.A.; Rehman, R.; Bhatti, L.A. Black Piper. In Medicinal Plants of South Asia, 1st ed.; Hanif, M.A., Nawaz, H., Khan, M.M., Birne, H.J., Eds.; Elsevier: Amsterdam, The Netherlands, 2019; pp. 75-86.

34. Tainter, D.R.; Grenis, A.T. Spices and Seasonings: A Food Technology Handbook; John Wiley \& Sons: Chichester, UK, 2001.

35. Lai, P.K.; Roy, J. Antimicrobial and chemo-preventive properties of herbs and spices. Curr. Med. Chem. 2004, 11, 1451-1460. [CrossRef]

36. Charles, D.J. Antioxidant Properties of Spices, Herbs, and Other Sources; Springer: New York, NY, USA, 2013 ; pp. $245-254$.

37. Parthasarathy, V.A.; Chempakam, B.; Zachariah, T.J. Chemistry of Spices; CABI International: London, UK, 2008 ; pp. 124-145.

38. Jayaprakasha, G.K.; Rao, L.J.; Sakariah, K.K. Chemical composition of volatile oil from Cinnamomum zeylanicum buds. Z. Nat. C 2002, 57, 990-993. [CrossRef] [PubMed]

39. Yashin, A.; Yashin, Y.; Xia, X.; Nemzei, B. Antioxidant activity of spices and their impact on human health: A review. Antioxidants 2017, 6, 70. [CrossRef]

40. Mathew, S.; Abraham, T.E. Studies on the antioxidant activities of cinnamon (Cinnamomum verum) bark extracts, through various in vitro models. Food Chem. 2006, 94, 520-528. [CrossRef]

41. Behrad, S.; Yusof, M.Y.; Goh, L.; Baba, A.S. Manipulation of probiotics fermentation of yoghurt by cinnamon and licorice: Effects on yogurt formation and inhibition of Helicobacter pylori growth in vitro. World Acad. Sci. Eng. Technol. 2009, 60, 590-594.

42. Forgetta, V.; Rempel, H.; Malouin, F.; Vaillanvourt Jn, E.; Topp, K.; Dewar, K.; Diarra, M.S. Pathogenic and multidrug-resistant Escherichia fergusonii from broiler chicken. Poult. Sci. 2012, 91, 512-525. [CrossRef] 
43. Lagacé-Wiens, P.R.; Baudry, P.J.; Pang, P.; Hammond, G. First description of an extended-spectrum- $\beta$-lactamase-producing multidrug-resistant Escherichia fergusonii strain in a patient with cystitis. J. Clin. Microbiol. 2010, 48, 2301-2302. [CrossRef] [PubMed]

44. Mahapatra, A.; Mahapatra, S. Escherichia fergusonii: An emerging pathogen in South Orissa. Indian J. Med Microbiol. 2005, 23, 204. [CrossRef]

45. Terzaghi, B.E.; Sandine, W.E. Improved medium for lactic Streptococci and their bacteriophages. Appl. Microbiol. 1975, $29,807-813$. [CrossRef] [PubMed]

46. Shankar, P.A.; Davies, F.L. Recent developments in yoghurt starters: A note on the suppression of Lactobacillus bulgaricus in media containing beta-glycerophosphate and application of such media to selective isolation of Streptococcus thermophilus from yoghurt. Soc. Dairy Technol. 1977, 30, 28-30. [CrossRef]

47. De Man, J.C.; Rogosa, M.; Sharpe, E.M. A medium for the cultivation of Lactobacilli. J. Appl. Bacteriol. 1960, $23,130-135$. [CrossRef]

48. Azwanida, N.N. A review on the extraction methods use in medicinal plants, principle, strength and limitation. Med. Aromat. Plants 2015, 4, 2167-0412.

49. Karenzi, E.; Mashaku, A.; Alphonse, M.; Munyanganizi, N.B.; Thonart, P. Kivuguto Traditional Fermented Milk and the Dairy Industry in Rwanda. A. Review. Biotechnol. Agron. Société Environ. 2013, 17, 383-391. Available online: https://popups.uliege.be/ 1780-4507/index.php?id=9985 (accessed on 1 September 2021).

50. Visvalingam, J.; Holley, R.A. Temperature-dependent effect of sublethal levels of cinnamaldehyde on viability and morphology of Escherichia coli. J. Appl. Microbiol. 2012, 113, 591-600. [CrossRef] [PubMed]

51. Cava, R.; Nowak, E.; Taboada, A.; Marin-Iniesta, F. Antimicrobial activity of clove and cinnamon essential oils against Listeria monocytogenes in pasteurized milk. J. Food Prot. 2007, 70, 2757-2763. [CrossRef] [PubMed]

52. Althair, M.O.E.; Elgasim, E.A.; Ahmed, I.A.M. Ripening of Sudanese braided (Muddafara) cheese manufactured from raw and pasteurized milk: Effect of heat treatment and salt concentration on the physiochemical properties. Int. J. Food Sci. 2014, 2, 1-7. [CrossRef]

53. Puvača, N.; Milenković, J.; Galonja Coghill, T.; Bursić, V.; Petrović, A.; Tanasković, S.; Pelić, M.; Ljubojević Pelić, D.; Miljković, T. Antimicrobial activity of selected essential oils against selected pathogenic bacteria: In vitro study. Antibiotics 2021, 10, 546. [CrossRef]

54. Ogwaro, B.A.; Gibson, H.; Whitehead, M.; Hill, D.J. Survival of Escherichia coli O157, H7 in traditional African yoghurt fermentation. Int. J. Food Microbiol. 2002, 79, 105-112. [CrossRef]

55. Moon, D.D.; Delaquis, P.; Toivonen, P.; Stanich, K. Effect of vanillin on the fate of Listeria monocytogenes and Escherichia coli O157, H7 in a model apple juice medium and in apple juice. Food Microbiol. 2006, 23, 169-174. [CrossRef]

56. Sinenky, M. Homeoviscous adaptation-A homeostatic process that regulates viscosity of membrane lipids in Escherichia coli. Proc. Natl. Acad. Sci. USA 1974, 71, 522-525. [CrossRef]

57. Horváth, I.; Glatz, A.; Varvasovszki, V.; Török, Z.; Páli, T.; Balogh, G.; Kovács, E.; Nádasdi, L.; Benkö, S.; Joó, F.; et al. Membrane physical state controls the signalling mechanism of the heat shock response in Synechocystis PCC 6803: Identification of hsp17 as a "fluidity gene". Proc. Natl. Acad. Sci. USA 1998, 95, 3513-3518. [CrossRef]

58. Wendakoon, C.; Sakaguchi, M. Inhibition of amino acid decarboxylase activity of Enterobacter aerogenes by active components in spices. J. Food Prot. 1995, 58, 280-283. [CrossRef] [PubMed]

59. Hyidgaard, M.; Mygind, T.; Meyer, R.L. Essential oils in food preservation: Mode of action, synergies, and interactions with food matrix components. Front. Microbiol. 2012, 3, 12. [CrossRef]

60. Helander, I.M.; Alakomi, H.L.; Latva-Kala, K.; Mattila-Sandholm, T.; Pol, I.; Smid, E.J.; Gorris, L.G.M.; von Wright, A. Characterization of the action of selected essential oil components on Gram-negative bacteria. J. Agric. Food Chem. 1998, 46, 3590-3595. [CrossRef]

61. Gill, A.O.; Holley, R.A. Disruption of Escherichia coli, Listeria monocytogenes and Lactobacillus sakei cellular membranes by plant oil aromatics. Int. J. Food Microbiol. 2006, 108, 1-9. [CrossRef]

62. Gill, A.O.; Holley, R.A. Mechanisms of bactericidal action of cinnamaldehyde against Listeria monocytogenes and of eugenol against L. monocytogenes and Lactobacillus sakei. Appl. Environ. Microbiol. 2004, 70, 5750-5755. [CrossRef] [PubMed]

63. Patil, U.K.; Singh, A.; Chakraborty, A.K. Role of piperine as a bioavailability enhancer. Int. J. Recent Adv. Pharm. Res. 2011, 4, 16-23.

64. Fitzerald, D.J.; Stratford, M.; Gasson, M.J.; Narbad, A. The potential application of vanillin in preventing yeast spoilage in soft drinks and fruit juices. J. Food Prot. 2004, 67, 391-395. [CrossRef]

65. Yossa, N.; Patel, J.; Macarisin, D.; Millner, P.; Murphy, C.; Bauchan, G.; Lo, Y.M. Antibacterial activity of cinnamaldehyde and Sporan against Escherichia coli O157:H7 and Salmonella. J. Food Process. Preserv. 2012, 38, 749-757. [CrossRef] 